\title{
Mengembangkan Etika Sosial Antara Siswa Dengan Guru Dalam Pembelajaran Pendidikan Agama Kristen Sistem Daring
}

\author{
Thomson Siallagan \\ Sekolah Tinggi Teologi Baptis Medan \\ thomsonsiallagan75@gmail.com
}

\begin{abstract}
During the 19th pandemic, the face-to-face learning system turned into a distance learning system. Children learn from home and teachers teach using the internet network. Various problems arise in this daring learning system, including problems of social ethics between students and teachers. This study aims to examine how to develop social ethics between students and teachers in daring learning during a pandemic. The research method used is the literature review method using literature related to the subject of study. The results of the study found in developing social ethics between students and teachers in daring learning during the pandemic are as follows: developing social ethics between students and teachers in participatory learning. Teachers, especially BP teachers, socialize the social ethic repeatedly with a collaborative system, which involves all education stakeholders, including parents and school committees. Teachers are gentle but firm in carrying out these social ethics. Teachers deal with students who lack ethics wisely and on the other hand, teachers are professional and become role models of social ethics in learning.
\end{abstract}

Keywords: social ethics; students; teachers; learning; Christian education; daring

\begin{abstract}
Abstrak
Di masa pandemi 19, sistem pembelajaran tatap muka berubah menjadi sistem pembelajaran jarak jauh. Anak belajar dari rumah dan guru mengajar dengan menggunakan jaringan internet. Berbagai persoalan muncul dalam sistem pembelajaran daring ini, termasuk masalah etika sosial antara siswa dengan guru. Penelitian ini bertujuan untuk mengkaji bagaimana mengembangkan etika sosial antara siswa dengan guru dalam pembelajaran daring di masa pandemi. Metode penelitian yang digunakan adalah metode kajian pustaka dengan menggunakan literatur-literatur yang berkaitan dengan subjek kajian. Hasil kajian yang ditemukan dalam mengembangkan etika sosial antara siswa dengan guru dalam pembelajaran daring di masa pandemi adalah sebagai berikut: mengembangkan etika sosial antara siswa dengan guru dalam pembelajaran secara partisipatif. Guru khususnya guru BP mensosialisasikan etika sosial tersebut secara berulang-ulang dengan sistem kolaboratif, yakni melibatkan semua stakeholder pendidikan, termasuk orang tua dan komite sekolah. Guru bersikap lembut tapi tegas dalam menjalankan etika sosial tersebut. Guru mengatasi siswa yang kurang beretika dengan bijaksana dan di lain pihak guru bersikap profesional dan menjadi teladan beretika sosial dalam pembelajaran.
\end{abstract}

Kata Kunci: etika sosial; siswa; guru; pembelajaran; pendidikan agama Kristen; daring 


\section{PENDAHULUAN}

Terhitung Maret 2020, organisasi kesehatan dunia, WHO menetapkan Corona Virus Disease (Covid-19) sebagai pandemi karena telah melanda lebih dari 200 negara di dunia. Sebagai langkah untuk mengantisipasi penyebaran virus Covid-19, pemerintah Indonesia melakukan tindakan, mulai dari kampanye dari rumah, pemberlakuan pembatasan social and physical distancing, pembatasan sosial berskala besar (PSBB), hingga pembelajaran dari rumah mulai tingkat TK sampai dengan Perguruan Tinggi melalui pembelajaran daring (dalam jaringan). Kebijakan-kebijakan tersebut diberlakukan dengan tujuan agar masyarakat tetap berada di rumah, bekerja, belajar dan beribadah di rumah. ${ }^{1}$ Meluasnya penyebaran Covid-19 telah mendorong pemerintah untuk menutup sekolah-sekolah dan mengadakan pembelajaran jarak jauh di rumah. Berbagai inisiatif dilakukan untuk memastikan kegiatan belajar tetap berlangsung meskipun tidak adanya sesi tatap muka langsung. ${ }^{2}$ sebagaimana dikatakan oleh Yusra Tebe, Konsultan Nasional Pendidikan dalam Situasi Darurat, UNICEF-RDI, "Saat kurang lebih 60 juta

1 Nadia Fairuza Azzahra, "Mengkaji Hambatan Pembelajaran Jarak Jauh Di Indonesia Di Masa Pandemi Covid-19," Ringkasan Kebijakan 19, no. 2 (2020): 1-9.

${ }^{2}$ Ibid. siswa di Indonesia tidak dapat bersekolah karena Covid-19. Dari jumlah tersebut angka terbanyak adalah pelajar SD sederajat dengan lebih dari 28 juta siswa, berikutnya SMP atau sederajat dengan 13 juta siswa, dan SMA atau sederajat 11 juta siswa. Kementerian Agama (Kemenag), yang mengawasi Madrasah, mengikuti himbauan tersebut dengan mengeluarkan Surat Edaran Nomor B686.1/DJ.I.I/PP.00/03/2020. ${ }^{3}$ Selain itu pemerintah juga sedang mempersiapkan kurikulum darurat dengan skenario belajar di rumah sampai bulan Januari $2021{ }^{4}$

Teknologi, spesifiknya internet, ponsel pintar, dan laptop saat ini digunakan secara luas dan sebagian sekolah mewajibkan penggunaan perangkat tersebut untuk mendukung pembelajaran jarak jauh. Salah satu penyedia jasa telekomunikasi terbesar di Indonesia mencatat peningkatan broadband sebesar $16 \%$ selama krisis Covid-19, yang disebabkan oleh tajamnya peningkatan penggunaan platform pembelajaran jarak jauh. Pembelajaran jarak jauh memiliki hambatan tersendiri bagi para siswa untuk mengakses pendidikan, maka itu diversifikasi media penyampaian selain internet perlu dipertimbangkan. Opsinya

\footnotetext{
${ }^{3}$ Ibid.

4 "Kemendikbud Terbitkan Pedoman Penyelenggaraan Belajar Dari Rumah," Kemendikbud, last modified 2020, accessed April 30, 2021, https://www.kemdikbud.go.id/
} 
bisa berupa program atau platform atau menggunakan layanan pos untuk daerahdaerah dengan konektivitas rendah. ${ }^{5}$ Penggunaan teknologi informasi dan komunikasi telah dimasukkan (IT) dalam kurikulum pelatihan. Akan tetapi, ada keraguan terhadap efektivitasnya mengingat isinya yang mayoritas tidak relevan dengan pembelajaran jarak jauh. Untuk kesuksesan adopsi pembelajaran jarak jauh, guru perlu untuk tidak hanya memiliki keterampilan teknologi dasar (seperti menggunakan komputer dan tersambung ke internet), tetapi juga pengetahuan untuk menggunakan perangkat-perangkat lunaknya secara profesional, serta metode untuk menyampaikan pelajaran tanpa interaksi tatap muka. Keterampilan tersebut sangat diperlukan ketika akan menggunakan platform belajar daring. Lebih penting lagi, kesenjangan antara skenario pelatihan dan eksekusi di lapangan perlu untuk diminimalkan. Oleh karena itu, model pembelajaran daring yang memusatkan tempat pembelajaran di rumah memiliki dampak negatif yang harus terus-menerus diupayakan untuk dicari jalan keluarnya.

Dari sekian banyak dampak di atas, maka masalah etika sosial antara siswa dan guru merupakan salah satu masalah yang

\footnotetext{
Azzahra, "Mengkaji Hambatan Pembelajaran Jarak Jauh Di Indonesia Di Masa Pandemi Covid-19."
}

segera perlu diselesaikan untuk menghasilkan pembelajaran daring yang lebih baik.

Secara teknis pembelajaran daring berbeda dengan pembelajaran tatap muka atau langsung. Pembelajaran daring memiliki bentuk permasalahan yang berbeda pula dari sistem pembelajaran tatap muka, di mana teknis pembelajaran ini lebih bebas dan bersifat personal karena tidak dibatasi ruang, hanya saja waktu pelaksanaan pembelajaran masih sesuai dengan ketetapan.

Etika sosial berbicara tentang kebiasaan individu dalam berperilaku, bersikap, serta tanggapannya terhadap norma yang berlaku, dalam hal ini khususnya norma di sekolah. Masalah etika sosial yang sering muncul dalam pembelajaran daring secara umum adalah menyangkut hubungan siswa dengan guru. Guru yang mestinya dihormati dan dihargai sekarang malah dilawan dan tidak lagi disegani. ${ }^{6}$ Siswa tidak memiliki sikap taat kepada guru, karena merasa jauh dari sekolah dan tidak diawasi oleh guru secara langsung. Tidak memperhatikan guru saat mengajar lewat platform classroom. Memang siswa bersangkutan seperti melihat tetapi sebenarnya pikirannya ke tempat lain, bahkan tidak jarang anak siswa

6 "Medan Bisnis Daily," Medan Bisnis Daily, last modified 2016, accessed April 30, 2021, https://www.medanbisnisdaily.com/. 
tersebut justru membuka program lain di handphone atau laptop dan bermain game, bahkan melihat konten-konten yang belum dapat diakses oleh anak usia sekolah.

Siswa tidak membiasakan diri untuk minta ijin dengan hormat, waktu pembelajaran classroom berlangsung. Sewaktu-waktu siswa meninggalkan tempat belajarnya seakan-akan pergi ke toilet pada saat jam pembelajaran berlangsung sehingga tidak membawa handphone atau laptopnya, padahal sebenarnya pergi ke tempat lain dan sedang sengaja menghindar untuk tidak belajar. Siswa tidak memiliki sikap rendah hati di hadapan guru. Dengan kemajuan teknologi informatika dewasa ini, sangat dimungkinkan siswa lebih up date terhadap perkembangan materi ajar lalu meremehkan pengetahuan gurunya. Siswa berani mencela kelemahan guru baik dalam hal kognitif maupun kemampuan mengajar, karena merasa tidak bertatap muka secara langsung. Siswa bertanya dengan kasar dan suka menyela perkataan guru dan berebut dengan siswa lain pada saat bersamaan, sehingga suasana belajar daring menjadi tidak kondusif. Siswa tidak menampilkan bahasa tubuh yang baik.

Bahasa tubuh siswa saat mengikuti pembelajaran acuh dan seakan-akan tidak menghargai pembelajaran yang sedang berlangsung sehingga sangat mengganggu guru saat memberikan pembelajaran, misalnya tidak melihat wajah guru yang sedang mengajar dan asyik dengan kegiatan lainnya. Anak memperlihatkan kesan sedang mendengarkan pelajaran selama google classroom padahal pada saat yang bersamaan mengakses kegiatan yang lain seperti game atau chatting dengan teman lain, Selama pembelajaran berlangsung anak cenderung mengakses hal-hal lain yang tidak berhubungan dengan pembelajaran, bahkan konten-konten yang belum bisa bagi anak-anak atau belajar sambil tiduran atau posisi tubuh tidak sopan karena merasa tidak sedang bersama dengan gurunya yang sedang menyajikan pembelajaran.

Bermain selama pembelajaran berlangsung dengan kegiatan-kegiatan yang lain. Tidak mengenakkan seragam sekolah selama pembelajaran berlangsung sehingga kelihatan tidak seperti sedang belajar sama sekali, melainkan seperti suasana bermain handphone. Siswa kurang menghormati guru sebagaimana mestinya. Karena merasa sangat akrab dan dekat dengan guru, lalu siswa memanggil namanya, meniru cara bicaranya sebagai bahan lelucon dan menyamakan gurunya seperti teman sebaya.

Pada penelitian sebelumnya yang dilakukan oleh I Wayan Eka Santika dalam Pendidikan Karakter pada Pembelajaran 
$\operatorname{Daring}^{7}$ ia membahas tentang perwujudan keseimbangan ranah kognitif, afektif, dan psikomotorik siswa dalam pendidikan karakter pada pembelajaran daring (daring) yang bermuara pada perwujudan manusia seutuhnya. Ia menjelaskan bahwa pembelajaran daring memiliki tantangan tersendiri pada guru dalam proses pendidikan karakter dalam pembelajaran daring sehingga guru harus memberikan kesempatan bagi peserta didik untuk mengaktualisasikan nilai-nilai karakter di dalam masyarakat, kemudian guru harus memiliki teknik dan strategi dalam pendidikan karakter pada pembelajaran daring, berusaha kreatif dalam menggali informasi, dan menentukan model-model pembelajaran untuk mendapatkan hasil belajar sesuai yang diharapkan.

Pada penelitian ini penulis akan fokus membahas tentang etika sosial, hal ini berkenaan dengan watak, kebiasaan, dan cara hidup yang sesuai selaku peserta didik sekalipun dalam pembelajaran daring dengan tujuan untuk membahas tentang pertemuan guru dengan siswa pada pengalaman belajar-mengajar yang integratif, karena pihak guru dan pihak peserta didik perlu saling memahami dalam proses belajar-mengajar demi hasil belajar sesuai yang diharapkan

7 I Wayan Eka Santika, "Pendidikan Karakter Pada Pembelajaran Daring," Indonesian

\section{METODE PENELITIAN}

Tulisan ini menggunakan metode penelitian kualitatif deskriptif. Teknik pengumpulan data yang digunakan ialah dengan pendekatan studi pustaka, yaitu pengumpulan dokumen berupa sumbersumber buku, jurnal, dan media lainnya yang mendukung pembahasan dalam tulisan ini.

\section{HASIL DAN PEMBAHASAN}

\section{Pentingnya Etika Sosial Antara Siswa dengan Guru dalam Pembelajaran Daring}

Masalah etika sosial antara siswa dengan guru, tidak hanya berasal dari siswa saja, melainkan juga dari guru itu sendiri. Pertama, guru kurang profesional. Guru yang profesional dalam bidangnya dengan tugas utamanya mendidik, mengajar, membimbing, mengarahkan, melatih, menilai dan mengevaluasi untuk diajarkan kepada peserta didik. Sebagai pendidik, ia harus memiliki standar kualitas integritas yang mencakup tanggung jawab, wibawa, mandiri, dan disiplin. Akan tetapi pada praktiknya, dalam pembelajaran daring, guru kurang memiliki profesionalisme. Sikap guru terhadap pekerjaan sebagai guru tidak profesional. Sikap guru merupakan

Values and Character Education Journal 3, no. 1 (2020): 8-19. 
keyakinan seorang guru mengenai pekerjaan yang diembannya, yang disertai adanya perasaan tertentu, dan memberikan dasar kepada guru tersebut untuk membuat respons atau berperilaku dalam cara tertentu sesuai pilihannya.

Sikap guru terhadap pekerjaan mempengaruhi tindakan guru tersebut dalam menjalankan aktivitas kerjanya. Bilamana seorang guru memiliki sikap positif terhadap pekerjaannya, maka sudah barang tentu guru akan menjalankan fungsi dan kedudukannya sebagai tenaga pengajar dan pendidik di sekolah dengan penuh rasa tanggung jawab. Demikian pula sebaliknya seorang guru yang memiliki sikap negatif terhadap pekerjaannya, pastilah dia hanya menjalankan fungsi dan kedudukannya sebatas rutinitas belaka. Untuk itu amatlah perlu kiranya ditanamkan sikap positif guru terhadap pekerjaan, mengingat peran guru dalam lingkungan pendidikan dalam hal ini sekolah amatlah sentral. Sikap guru terhadap pekerjaan dapat dilihat dalam bentuk persepsi dan kepuasannya terhadap pekerjaan maupun dalam bentuk motivasi kerja yang ditampilkan

Dengan adanya etika siswa dengan guru dalam pembelajaran maka Guru merasa tenang dalam melaksanakan pembelajaran karena tidak terganggu dengan sikap siswa, sebaliknya siswa juga merasa tenang belajar karena guru juga bersikap profesional mengajar. Dengan begitu maka proses pembelajaran berjalan dengan nyaman, dinamis dan konstruktif. Dengan demikian maka harapan untuk mendapatkan hasil belajar yang memuaskan akan mudah tercapai. Tidak kalah penting dari adanya etika siswa dengan guru adalah terciptanya hubungan siswa dengan guru hangat tanpa sekat tetapi tetap disertasi rasa hormat dan profesionalisme.

\section{Mengembangkan Etika Sosial Antara Siswa dengan Guru}

Dalam proses belajar-mengajar, guru mendidik, mengajar, melatih, menilai, mengevaluasi serta yang membantu siswa untuk memahami dan mengalami pembelajaran. Supaya proses pembelajaran berjalan dengan baik, maka siswa harus menghormati guru melalui etika yang baik. Untuk mengatasi siswa yang memiliki etika kurang baik dalam pembelajaran daring adalah sebagai berikut: meningkatkan kualitas pendidikan karakter terutama melalui pendidikan agama.

Strategi dan langkah mengatasi siswa kurang beretika. Salah satu langkah penting dalam membangun dan mengembangkan etika sosial antara siswa dengan guru adalah memastikan pendidikan karakternya berjalan dengan baik. Menurut Ryan \& Bohlin (1999), karakter merupakan suatu pola perilaku seseorang. Orang yang berkarakter baik 
memiliki pemahaman tentang kebaikan, menyukai kebaikan, dan mengerjakan kebaikan tersebut. Orang yang perilakunya sesuai dengan kaidah moral disebut dengan berkarakter mulia. ${ }^{8}$ Pengertian karakter menurut Pusat Bahasa Depdiknas (2008) adalah "bawaan, hati, jiwa, kepribadian, budi pekerti, perilaku, personalitas, sifat, tabiat, temperamen, watak". Adapun berkarakter adalah berperilaku, bersifat, bertabiat, dan berwatak". 9

Pendidikan karakter adalah segala sesuatu yang dilakukan guru, yang mampu mempengaruhi karakter peserta didik. Guru membantu membentuk watak peserta didik. Hal ini mencakup keteladanan bagaimana perilaku guru, cara guru berbicara atau menyampaikan materi, bagaimana guru bertoleransi, dan berbagai hal terkait lainnya. Menurut T. Ramli (2001), pendidikan karakter memiliki esensi dan makna yang sama dengan pendidikan moral dan pendidikan akhlak. Tujuannya adalah membentuk pribadi anak, supaya menjadi manusia yang baik, warga masyarakat, dan warga negara yang baik. ${ }^{10}$ Adapun kriterianya adalah nilai-nilai sosial tertentu yang banyak dipengaruhi oleh budaya masyarakat dan bangsanya. Oleh

${ }^{8}$ Karen E. Ryan, Kevin; Bohlin, Building Character In Schools (San Fransisco: Jossey Bass, 1999).

9 Depdiknas, Kamus Besar Bahasa Indonesia Pusat Bahasa (Jakarta: PT Gramedia Pustaka Utama, 2008).

10 Irma Rahmayani, "Pengaruh Gaya karena itu, hakikat dari pendidikan karakter dalam konteks pendidikan di Indonesia adalah pendidikan nilai, yakni pendidikan nilai-nilai luhur yang bersumber dari budaya bangsa Indonesia sendiri, dalam rangka membina kepribadian generasi muda. ${ }^{11}$ Beberapa ciri orang yang memiliki karakter antara lain: hormat, tanggung jawab, peduli, disiplin, loyal, berani, dan toleran. Seseorang yang berkarakter mulia memiliki pengetahuan tentang potensi dirinya, yang ditandai dengan nilai-nilai seperti percaya diri, rasional, logis, kritis, analitis, kreatif dan inovatif, mandiri, hidup sehat, bertanggung jawab, sabar, berhatihati, rela berkorban, pemberani, dapat dipercaya, jujur, menepati janji, adil, rendah hati, ramah, cinta keindahan (estetis), sportif, dan tabah. Individu juga memiliki kesadaran untuk berbuat yang terbaik atau unggul, dan bertindak sesuai potensi dan kesadarannya.

David Elkind \& Freddy Sweet menyatakan bahwa pendidikan karakter merupakan upaya-upaya untuk membantu peserta didik memahami, peduli, dan berperilaku sesuai nilai-nilai etika yang

Belajar Terhadap Prestasi Belajar Mahasiwa," Fakultas Kedoteran, 2017.

${ }^{11}$ Freddy Elkind, David H; Sweet, "How to Teach Character Education," Good Character, accessed April 30, 2021, https://www.goodcharacter.com/how-toarticles/how-to-teach-character-education/. 
berlaku. ${ }^{12}$ Individu yang berkarakter baik atau unggul adalah seseorang yang berusaha melakukan hal-hal yang terbaik terhadap Tuhan, dirinya, sesama, lingkungan, bangsa dan negara serta dunia internasional pada umumnya dengan mengoptimalkan potensi (pengetahuan) dirinya dan disertai dengan kesadaran, emosi dan motivasinya (perasaannya). Dengan demikian, maka salah satu faktor penting yang mempengaruhi perilaku siswa adalah Pendidikan yang diterimanya, terutama pendidikan karakter.

Agama merupakan hal yang sangat hakiki bagi setiap orang di dunia ini, karena agama merupakan sarana bagi individu untuk mengaplikasikan rasa hormat kepada sesuatu yang dipercaya yang juga bersifat transenden. Dengan demikian, Pendidikan agama dimaksud-kan untuk peningkatan potensi spiritual dan membentuk peserta didik agar menjadi manusia yang beriman dan bertakwa kepada Tuhan Yang Maha Esa dan berakhlak mulia. Di mana akhlak mulia tersebut mencakup etika, budi pekerti, dan moral sebagai perwujudan dari pendidikan agama.

Pendidikan agama merupakan salah satu cara efektif dan strategis untuk mengembangkan etika sosial antara siswa dengan guru. Siswa yang tekun belajar agama akan mudah menerapkan nilai-nilai agama yang dipelajarinya dalam bentuk etika sosial.

Mata pelajaran pendidikan agama Kristen menjadi sangat penting untuk menjadi pijakan dalam pembinaan karakter siswa, mengingat tujuan akhir dari pendidikan agama tidak lain adalah terwujudnya akhlak atau karakter mulia. Tentu saja misi pembentukan karakter ini tidak hanya diemban oleh pendidikan agama, tetapi juga oleh pelajaran pelajaran lain secara bersama-sama. Meskipun demikian, pendidikan agama dapat dijadikan basis yang langsung berhubungan dengan pembinaan karakter siswa, terutama karena hampir semua materi pendidikan agama sarat dengan nilai-nilai karakter. Di samping itu, aktivitas keagamaan di sekolah yang merupakan bagian dari pendidikan agama dapat dijadikan sarana untuk membiasa-kan siswa memiliki karakter mulia termasuk memiliki etika sosial yang baik dengan gurunya. Menurut Peraturan Menteri Agama Republik Indonesia Nomor 16 Tahun 2010 Tentang Pengelolaan Pendidikan Agama Pada Sekolah, Pendidikan agama adalah pendidikan yang memberikan pengetahuan dan membentuk sikap, kepribadian, dan keterampilan peserta didik dalam mengamalkan ajaran agamanya, yang dilaksanakan sekurang-kurangnya melalui mata pelajaran pada semua jalur, jenjang dan jenis pendidikan. 
Pendidikan Agama Kristen sebagai bagian dari pendidikan-pendidikan agama menjadi sangat penting untuk menjadi pijakan dalam pembinaan karakter siswa. PAK yang diterima di sekolah dapat mempengaruhi penguatan karakter siswa. PAK adalah salah satu bidang pendidikan yang mengajarkan firman agar siswa memiliki pedoman dalam kehidupannya dan pada akhirnya mereka mengalami perubahan, karena firman Allah bermanfaat untuk mengajar, menyatakan kesalahan, memperbaiki kelakuan, dan mendidik orang dalam kebenaran ( II Tim 3:16).

\section{Menetapkan Etika Pembelajaran}

Secara Partisipatif. Dalam menetapkan etika pembelajaran secara partisipatif ada beberapa langkah yang harus dilakukan, yaitu sebagai berikut: Pada awal pembelajaran, terutama pada awal semester, Guru terutama guru BP mengorientasi siswa dengan didampingi orang tua sebagai pendamping anak dalam belajar daring dengan berbagai peraturan sekolah termasuk etika sosial belajar daring. Dalam orientasi tersebut, guru mengajak siswa berdiskusi tentang pentingnya etika dalam pembelajaran daring. ${ }^{13}$ Guru melibatkan siswa untuk ikut menambah atau mengurangi berbagai poin etika yang harus dimiliki oleh siswa dan

\footnotetext{
${ }^{13}$ Hendra Crisvin Manuliang, "Pendidikan Agama Kristen (PAK)," 3 Maret 2017 (2017).

14 Nurul Huda, "Pendekatan-Pendekatan
}

guru dalam pembelajaran, berdasar-kan diskusi di atas. Guru melibatkan siswa untuk ikut menyepakati reward dan punishment terhadap keberhasilan atau kegagalan dalam menjalankan etika yang sudah disepakati dalam bentuk tahapantahapan yang rasional dan tidak bersifat memaksa. Meminta siswa menuliskan dan menempelkan poin-poin etika di buku atau kamar masing-masing dengan jelas dan menarik sebagai pengingat siswa. Menciptakan suatu tagline etika yang menarik sebagai pengingat bagi siswa, menyusul salam pembuka kelas daring, sehingga lama-kelamaan poin-poin etika dalam pembelajaran maupun etika di sekolah mendarah daging bagi siswa. Melibatkan orang Tua untuk mendukung strategi dan langkah yang diambil dan dilakukan. ${ }^{14}$ Melibatkan Komite mendukung sepenuhnya strategi dan langkah yang telah diambil dan disepakati Berikutnya, Guru Mensosialisasikan dan Menjalankan Poin Etika Secara Kolaboratif. Sekolah meningkatkan peran Bimbingan Konseling secara holistik. Guru BP tidak hanya berperan ketika ada siswa yang melanggar aturan, tetapi pembina etika siswa secara berkala bekerja sama dengan guru-guru Mapel lainnya terutama guru agama. Guru BP melaksanakan

Pengembangan Kurikulum" II, no. September (2019): 175-197. 
pertemuan berkala dengan siswa dan jika dirasa perlu melibatkan orang tua mensosialisasikan etika siswa dengan guru dalam pembelajaran. Sekolah mengembangkan Kebijakan Kurikulum Berbasis Akhlak. Mata Pelajaran agama harus mengorientasikan pelajaran etika secara berkelanjutan. Guru BP sesering mungkin untuk mensosialisasikan dan mengevaluasi etika siswa dengan sesekali melibatkan orang tua sebagai pengawas pembelajaran daring. Guru harus menampilkan cermin keteladanan dari poin etika yang telah disepakati bersama.

Guru Bersikap Sabar, Lembut Tetapi Tegas. Untuk memastikan etika pembelajaran berjalan dengan baik, maka guru harus bersikap sabar, lembut tetapi tegas. Siswa adalah pelajar termasuk dalam hal etika, ia pun masih sedang belajar. Untuk itu maka guru harus sabar jika siswa tidak beretika sebagaimana mestinya. Menegur dengan lembut siswa yang kurang beretika, menghindari godaan untuk memaki dan memarahi dengan cara emosional atau merendahkan siswa. Guru tidak boleh menyerang siswa dengan katakata kurang pantas apalagi serangan psikis, seperti merendahkan siswa. Bersikap tegas memberi disiplin kepada siswa yang kurang beretika tanpa memandang muka atau pilih kasih sesuai dengan tahapan-tahapan yang telah disepakati bersama. Semua guru memiliki pemahaman yang sama atas etika pembelajaran yang sudah disepakati. Tidak ada perbedaan perlakuan di antara para guru kepada para siswa dalam menjalankan etika pembelajaran. Guru memberitahu kepada Orang tua/wali siswa mengenai poin etika pembelajaran sehingga mereka berperan untuk mengingatkan anaknya, termasuk ketika anaknya melakukan pelanggaran etika.

Menghadapi siswa kurang ber-etika Secara Personal dan Bijaksana. Guru tidak boleh memarahi siswa kurang beretika di hadapan banyak siswa lainnya atau pada saat belajar daring berlangsung, melainkan berbicara dengan empat mata. Guru meminta siswa untuk menilai diri sendiri apakah perbuatannya sudah melanggar etika atau tidak, sehingga siswa insaf. Guru meminta kesadaran siswa untuk menjalani disiplin atau punishment yang telah disepakati.

Di lain pihak, guru juga harus profesional dalam mengajar dan memiliki moral yang baik sehingga dirinya menjadi model dalam beretika pembelajaran. Hal ini sangat penting bagi siswa karena ia bukan saja belajar tentang pengetahuan tetapi juga menerima nilai-nilai dan sikap-sikap yang baik dari gurunya. Dengan demikian maka pengembangan etika belajar akan terjadi dengan baik dan alamiah. 


\section{Mengembangkan Etika Sosial Antara Siswa dengan Guru dalam PAK Sistem Daring}

Secara etimologi kata "etika" berasal dari bahasa Yunani yang terdiri dari dua kata yaitu Ethos dan ethikos. Ethos berarti sifat, watak kebiasaan, tempat yang biasa. Ethikos berarti susila, keadaban, kelakuan dan perbuatan yang baik. ${ }^{15}$ Istilah moral berasal dari kata latin yaitu mores, yang merupakan bentuk jamak ${ }^{e e}$ dari mos, yang berarti adat istiadat atau kebiasaan watak, kelakuan, tabiat, dan cara hidup. ${ }^{16}$ Etika dipahami sebagai ajaran yang berisi perintah dan larangan tentang baik buruknya perilaku manusia, yaitu perintah yang harus dipatuhi dan larangan yang harus dihindari. ${ }^{17}$ Etika adalah nilai dan standar moral, yang menjadi pedoman bagi seseorang atau kelompok dalam pengaturan perilaku. Pengertian etika menurut KBBI adalah ilmu yang mempelajari tentang baik buruk, hak dan kewajiban moral. Diartikan sebagai seperangkat prinsip atau nilai yang berkaitan dengan kesusilaan dan kesusilaan, diartikan sebagai nilai tentang apa yang benar dan salah yang dianut oleh masyarakat. ${ }^{18}$

Dalam penelitian ini, etika yang akan dibahas adalah etika sosial, yaitu etika

${ }^{15}$ Lorens Bagus, Kamus Filsafat (Jakarta: PT Gramedia Pustaka Utama, 2000). 217

${ }^{16}$ Ibid. 672

${ }^{17}$ Hasbullah Bakry, Sistematika Filsafat (Jakarta: Jakarta Wijaja, 1978). 9 yang berkaitan dengan perilaku manusia sebagai makhluk sosial dan interaksinya dengan manusia lain, dalam etika siswa terhadap guru dan sebaliknya di lingkungan sekolah.

Selain itu, kegiatan pembelajaran daring tiba-tiba mengubah teknik penilaian yang digunakan oleh guru. Menurut program tahun 2013, penilaian kegiatan pembelajaran meliputi aspek afektif, kognitif dan psikomotorik. Menurut Anderson ada tiga prinsip dalam penilaian kegiatan pembelajaran. Pembelajaran yang bermakna, transparan, dan adil. Ketiga prinsip tersebut tidak dapat dipatuhi secara optimal oleh guru. Terutama prinsip adil. Keadilan dalam penilaian artinya setiap siswa mempunyai kesempatan yang sama dalam sistem penilaian, bukan berarti setiap siswa menerima nilai yang sama, tetapi mendapat nilai yang sesuai dengan keterampilan belajarnya. Yudi Heriana Tantri, menyebutkan fakta di lapangan yang menunjukkan bahwa semua siswa mendapatkan nilai maksimal ketika ditanya. Menjadi pertanyaan bagi guru, apakah siswa benar-benar memahami materi atau apakah siswa dibantu oleh orang dewasa dalam mengerjakan tugas. ${ }^{19}$

\footnotetext{
18 "Kamus Besar Bahasa Indonesia (KBBI)," last modified 2012, accessed March 10, 2021, https://kbbi.web.id/murid.

19 Yudi Heriana Tantri, "Kendala Dan Solusi Belajar Pada Masa Covid-19," Koran Bernas,
} 
Bagi anak-anak yang ingin meraih nilai tinggi tetapi enggan belajar, mereka cenderung menjawab soal-soal ujian di internet meskipun sudah dilarang oleh guru.

Bahkan kecenderungan menjadi plagiat dalam mengerjakan tugas-tugas dengan tinggal copy-paste dari internet atau bertanya kepada orang lain tanpa berusaha untuk mencari jawabannya sendiri.

Masalah etika sosial antara siswa dengan guru, tidak hanya berasal dari siswa saja, melainkan juga dari guru itu sendiri. Pertama, guru kurang profesional. Guru yang profesional dalam bidangnya dengan tugas utamanya mendidik, mengajar, membimbing, mengarahkan, melatih, menilai dan mengevaluasi untuk diajarkan kepada peserta didik. Sebagai pendidik, ia harus memiliki standar kualitas integritas yang mencakup tanggung jawab, wibawa, mandiri, dan disiplin. Akan tetapi pada praktiknya, dalam pembelajaran daring, guru kurang memiliki profesionalisme. Sikap guru terhadap pekerjaan sebagai guru tidak profesional. Sikap guru merupakan keyakinan seorang guru mengenai pekerjaan yang diembannya, yang disertai adanya perasaan tertentu, dan memberikan dasar kepada guru tersebut untuk membuat respons atau berperilaku dalam cara tertentu sesuai pilihannya. ${ }^{20}$

last modified 2020, accessed April 25, 2021, https://www.koranbernas.id/kendala-dan-solusibelajar-pada-masa-covid19.
Sikap guru terhadap pekerjaan mempengaruhi tindakan guru tersebut dalam menjalankan aktivitas kerjanya. Bilamana seorang guru memiliki sikap positif terhadap pekerjaannya, maka sudah barang tentu guru akan menjalankan fungsi dan kedudukannya sebagai tenaga pengajar dan pendidik di sekolah dengan penuh rasa tanggung jawab. Demikian pula sebaliknya seorang guru yang memiliki sikap negatif terhadap pekerjaannya, pastilah dia hanya menjalankan fungsi dan kedudukannya sebatas rutinitas belaka. Untuk itu amatlah perlu kiranya ditanamkan sikap positif guru terhadap pekerjaan, mengingat peran guru dalam lingkungan pendidikan dalam hal ini sekolah amatlah sentral. Sikap guru terhadap pekerjaan dapat dilihat dalam bentuk persepsi dan kepuasannya terhadap pekerjaan maupun dalam bentuk motivasi kerja yang ditampilkan

Guru yang memiliki sikap positif terhadap pekerjaan jelas akan menunjukkan persepsi dan kepuasan yang baik terhadap pekerjaannya, serta motivasi yang kuat dalam bekerja, yang pada gilirannya akan mencerminkan seorang guru yang mampu bekerja secara profesional dan memiliki kompetensi profesional yang tinggi. Sikap positif maupun negatif seorang guru terhadap pekerjaan tergantung dari guru

\footnotetext{
${ }^{20}$ Ngalim Purwanto, Ilmu Pendidikan Teoretis Dan Praktis (Bandung: Remaja Rosdakarya, 1994).
} 
bersangkutan maupun kondisi lingkungan.

Menurut Walgito, sikap yang ada pada diri seseorang dipengaruhi oleh faktor internal yaitu faktor fisiologis dan psikologis, serta faktor eksternal terutama berupa situasi yang dihadapi individu, norma dan berbagai hambatan maupun dorongan yang ada dalam masyarakat. Surya "mengemukakan kompetensi profesional adalah berbagai kemampuan yang diperlukan agar dapat mewujudkan dirinya sebagai guru profesional." 21

Kompetensi profesional meliputi kepakaran atau keahlian dalam bidangnya yaitu penguasaan bahan yang harus diajarkan beserta metode dipilih, rasa tanggung jawab akan tugas dan rasa kebersamaan dengan para guru yang lain. Salah satu peran guru adalah sebagai profesional. Kedudukan seorang guru sebagai seorang profesional memerlukan peningkatan keterampilan dan kualitas guru secara terus menerus. Guru yang berkualifikasi profesional, yaitu guru yang memiliki pemahaman menyeluruh tentang apa yang diajarkan, kompeten dalam pengajaran yang efektif dan efisien, dan guru memiliki kepribadian yang kuat. Selain itu, integritas diri dan keterampilan guru juga harus dipupuk dan

21 Muhammad Surya, Psikologi Pembelajaran Dan Pengajaran (Bandung: Yayasan Bakti Winaya, 2003). 138

22 Herwansyah Hermawansyah, "Etika dikembangkan. Selain itu, guru harus memiliki akhlak yang tinggi dan keimanan yang dalam di seluruh perilakunya. Memang guru harus bersikap jujur, disiplin, setia, setia, beretika dan menghayati iman yang hidup. Guru juga harus memiliki kapasitas kerja yang baik dan kedewasaan berpikir yang besar karena guru sebagai pemegang jabatan profesional merupakan kedudukan yang strategis dalam kehidupan dan pembangunan masyarakat. Guru juga harus bisa memantapkan posisi dan perannya lewat usaha-usaha mengembangkan kemampuan diri secara maksimal dan berkesinambungan dalam belajar lebih lanjut. Salah satu yang melandasi pentingnya seorang guru, harus terus berusaha mengembangkan diri karena pendidikan berlangsung sepanjang hayat. ${ }^{22}$

Berikutnya, seorang guru tidak memiliki kepribadian yang baik. Bukan hanya pintar secara kognitif dan kreatif dalam mengajar. Guru yang seharusnya menjadi figur atau contoh yang baik bagi peserta didik atau menjadi teladan bagi siswa dalam pembentukan karakter tidak mampu berperan dengan baik sebagai panutan. Guru sebagai pendidik yang menjadi tokoh panutan tidak bertanggung jawab, berwibawa, dan disiplin dalam

Guru Sebagai Pendidikan Yang Mendasar Bagi Siswa," Jurnal Studi Pendidikan 10, no. 2 (2019): 32-33. 
menjalankan semua peraturan sekolah secara konsisten. Guru yang tidak memiliki kepribadian baik tidak bersikap baik kepada siapa saja, terutama kepada anak didik yang di ajarnya. "Guru sangat berperan dalam membantu perkembangan peserta didik untuk mewujudkan tujuan hidupnya secara optimal. Ketika orang tua mendaftarkan anaknya ke sekolah, pada saat itu juga ia menaruh harapan terhadap guru, agar anaknya dapat berkembang secara

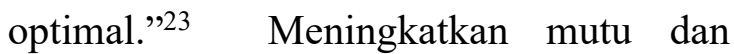
kualitas pendidik yang profesional saat ini tidak cukup hanya menguasai pengetahuan dan pandai secara akademis. Status sebagai guru dapat dipandang sebagai yang tinggi atau rendah, tergantung di mana ia berada. Sedangkan perannya yang berkedudukan sebagai pendidik seharusnya menunjuk-kan kelakuan yang layak sesuai harapan masyarakat, dan guru diharapkan berperan sebagai teladan dan rujukan dalam masyarakat dan khususnya bagi anak didik yang diajar.

Guru tidak hanya memiliki satu peran saja, ia bisa berperan sebagai orang yang dewasa, sebagai seorang pengajar dan sebagai seorang pendidik, sebagai pemberi contoh dan sebagainya. Akan tetapi, seorang guru harus memiliki moral dan akhlak yang baik sehingga menjadi teladan bagi peserta didiknya. Kualitas pola

${ }^{23}$ E. Mulyasa, Menjadi Guru Professional, Menciptakan Pembelajaran Kreatif Dan pendidikan yang disampaikan seorang guru yang memiliki profesionalisme tinggi tentu akan sangat berpengaruh pada kualitas anak didiknya. Para guru pun harus menjunjung tinggi moral, mengajar hanyalah kegiatan sekadar menyampaikan sesuatu secara tersistem. Berbeda dengan mendidik. Kegiatan mendidik bertujuan untuk membentuk karakter peserta didik. Kegiatan mendidik akan terlaksana dengan baik jika pendidiknya dapat menjadi teladan bagi peserta didik. Artinya, mereka harus menjadi contoh dengan sikap yang beretika atau bermoral. Jika ini tidak diindahkan, wajarlah siswanya tidak bermoral seperti gurunya. Guru wajib bersikap santun dalam profesinya.

Seorang guru yang baik adalah guru yang dapat memberikan inspirasi untuk para muridnya. Inspirasi ini ditunjukkan para guru dengan memberikan teladan dan nasihat membangun pada anak-anak didik agar mereka belajar tanpa rasa takut jika salah dan dikatakan tidak mampu.

\section{Etika Murid Terhadap Guru dalam Pembelajaran Daring}

Mengingat keunikan dari Pembelajaran Jarak Jauh, perlu ada langkah strategis dan komprehensif dalam mengembangkan etika sosial antara siswa dengan guru adalah berupa langkah taktis

Menyenangkan (Bandung: Remaja Rosdakarya, 2005). 10 
yang harus segera diterapkan oleh sekolah. ${ }^{24}$ Beberapa etika siswa terhadap guru di sekolah, yang perlu dimiliki oleh siswa adalah sebagai berikut: Siswa memiliki sikap taat kepada guru. Guru bukan saja seorang pendidik, melainkan juga orang tua di sekolah. Oleh karena itu, siswa tidak hanya taat dan patuh kepada aturan sekolah tetapi kepada guru juga. Misalnya mengerjakan tugas yang diberikan guru pada tepat waktu.

Siswa memperhatikan guru saat mengajar atau menasihati. Dalam proses pembelajaran daring sangat penting bagi siswa untuk memperhatikan apa yang sedang disampaikan oleh guru. Tujuannya bukan saja supaya siswa memahami materi, tetapi juga sebagai sikap hormat dan menghargai guru. ${ }^{25}$ Siswa membiasakan diri untuk minta ijin dengan hormat. Jika sewaktu-waktu siswa harus meninggalkan tempat belajar daring atau classroom karena ada keperluan mendesak seperti ke toilet pada saat jam pembelajaran berlangsung, maka siswa harus minta ijin dengan hormat seraya memberi alasan.

Siswa tidak boleh mencela dan kelemahan gurunya. Sebagaimana manusia lain tidak sempurna, maka demikian pula seorang guru tidak lepas dari kekurangan

\footnotetext{
24 Imam Qori, “Analisis Dampak Pembelajaran Daring Terhadap Guru Dan Peserta Didik Perspektif Teori Etika” (2019).

25 Delipiter Lase and Etty Destinawati Hulu, "Dimensi Spritualitas Dalam Kompetensi
}

dan kelemahan. Siswa tidak boleh mencela kekurangan guru baik dalam hal kognitif maupun kemampuan mengajar. Siswa bertanya dengan lemah lembut dan tidak menyela perkataan guru. Sewaktu guru memberikan kesempatan untuk bertanya, maka siswa harus bertanya dengan lemah lembut dan tidak boleh menyela saat guru misalnya sedang menjawab dan siswa merasa tidak puas dengan jawaban tersebut. Siswa harus menunggu sampai guru selesai berbicara dan mohon ijin untuk diberi kesempatan berbicara kembali.

Siswa bersikap rendah hati di hadapan guru. Dengan kemajuan teknologi informatika dewasa ini, sangat dimungkinkan siswa lebih update terhadap perkembangan materi ajar. Jika siswa ingin memberitahu perkembangan pengetahuan tersebut, maka ia harus minta ijin dan memberitahu dengan sikap rendah hati. Siswa tidak boleh meremehkan pengetahuan guru. Jika sekiranya siswa berbuat suatu kekeliruan atau telah melakukan pelanggaran terhadap peraturan dan perintah guru, maka ia harus meminta maaf dengan sikap tulus, ikhlas, sopan dan hormat kepada guru.

Siswa menampilkan bahasa tubuh yang baik. Bahasa tubuh merupakan bagian

Kepribadian Guru Pendidikan Agama Kristen," SUNDERMANN: Jurnal Ilmiah Teologi, Pendidikan, Sains, Humaniora dan Kebudayaan 13, no. 1 (2020): 13-25. 
dari etika yang sangat penting, karena bahasa tubuh dapat memberi pesan kepada orang lain atau guru lebih kuat daripada kata-kata verbal terutama dalam pembelajaran daring. Oleh karena itu siswa harus belajar bagaimana sikap duduk, berdiri, berjalan, melihat dan menampilkan mimik wajah di depan kamera di hadapan gurunya.

Siswa menerima nasehat bahkan teguran dengan sikap hormat. Ada kalanya siswa dinasihati bahkan ditegur oleh guru di mana menurut sudut pandang siswa nasehat dan teguran tersebut dengan tidak memiliki dasar yang kuat dan tepat. Dalam hal ini, siswa harus bersikap hormat, dan sekiranya pen-jelasan siswa tidak diterima oleh guru, maka siswa harus menunggu kesempatan lain untuk memberitahu duduk perkara yang sebenarnya dengan tetap sikap hormat. Siswa membangun integritas yang baik. Kadang-kadang ada kalanya siswa tidak mengerjakan tugasnya, terlambat tiba di sekolah, bolos, atau perilaku kurang baik lainnya. Sangat penting bagi siswa untuk tidak berbohong kepada guru, karena mengakui kesalahan lebih baik daripada menutupi kesalahan.

Siswa menghormati guru sebagaimana mestinya. Sekalipun siswa sangat dekat dengan gurunya, namun ia tidak boleh memanggil namanya, mendahuluinya saat berjalan tanpa basa-

${ }^{26}$ Hilmi Mubarok Putra, Deka Setiawan, and Nur basi, menduduki tempat duduknya, meniru cara bicaranya sebagai bahan lelucon dan terlalu dekat sehingga menyamakannya seperti teman sebaya. Siswa mendoakan gurunya seperti mendoakan orang tuanya sendiri. Guru merupakan orang tua kedua dan sangat berjasa kepada siswa. Sangat jarang ada kesempatan bagi siswa untuk membalas jasa guru-gurunya, itulah sebabnya para guru disebut "Pahlawan Tanpa Tanda Jasa". Mendoakan dan mengharapkan yang terbaik untuk setiap guru merupakan cara terbaik untuk menghargai guru. Ini juga bagian dari etika siswa terhadap gurunya.

Siswa tidak terlalu sering meninggalkan tempat belajar dengan apalagi membawa gadget ke mana-mana sambil mendengar guru mengajar. Selain mengganggu siswa bersangkutan, maka hal ini juga mengganggu guru yang mengajar karena latar belajar siswa bersangkutan sering berubah-ubah dan mungkin disertai suara-suara yang mengganggu. Tidak kalah penting dari pihak guru, ia harus bersikap profesional dalam mengajar. Belajar secara daring tidak boleh dijadikan sebagai alasan untuk memperpendek jam tatap muka classroom atau memberikan tugas-tugas secara berlebihan kepada siswa sehingga menimbulkan rasa syak pada siswa kepada gurunya. ${ }^{26}$

Terakhir, guru harus menjunjung Fajrie, "Perilaku Kedisiplinan Siswa Dilihat Dari 
tinggi moral dan mengajar secara baik. Guru harus dapat menempatkan dirinya sebagai teladan bagi siswanya dalam menampilkan bahasa tubuh maupun dalam berkomunikasi verbal. Karena dalam pembelajaran daring, siswa fokus kepada angel guru yang sedang mengajar, maka sangat penting bagi guru tersebut untuk menunjukkan sikap serius dan peduli kepada siswa dan pembelajaran itu sendiri. Jika ada guru yang biasa merokok di rumah, maka sangat diharuskan dalam pembelajaran daring, guru tidak merokok.

\section{KESIMPULAN}

Dengan memperhatikan paparan etika sebagaimana diuraikan di atas maka dapat disimpulkan bahwa etika siswa terhadap guru memiliki posisi yang sangat urgen dalam pembelajaran. Etika siswa terhadap guru begitu penting karena bukan saja bagian dari pembinaan karakter bagi siswa tetapi juga menjadi syarat mutlak untuk menciptakan pembelajaran menjadi ancar, dinamis, komunikatif, konstruktif dan hangat sehingga proses pembelajaran sebagai transmisi pengetahuan, attitude dan nilai akan berjalan dengan baik dan pada akhirnya siswa akan berprestasi dan sekolah akan berkualitas.

Etika siswa terhadap guru begitu penting karena bukan saja bagian dari

Etika Belajar Di Dalam Kelas," Prakarsa pembinaan karakter bagi siswa tetapi juga menjadi syarat mutlak untuk menciptakan pembelajaran menjadi lancar, dinamis, komunikatif, konstruktif dan hangat sehingga proses pembelajaran sebagai transmisi pengetahuan, attitude dan nilai akan berjalan dengan baik dan pada akhirnya siswa akan berprestasi dan sekolah akan berkualitas.

Etika terhadap guru sangat berperan penting bagi siswa untuk keberhasilannya sendiri sebagai siswa, baik pada masa belajar maupun kelak di masa depan. Memperlakukan guru dengan etika yang baik merupakan cara yang baik dalam menempatkan diri sendiri untuk menerima etika yang baik pula dari orang lain termasuk guru. Karena itu, maka sangat penting bagi siswa untuk memiliki etika sebagaimana diuraikan di atas. Maka sangat penting agar guru, siswa dan orang tua terus-menerus berkolaborasi mensosialisasikan pentingnya etika pembelajaran bukan dengan hanya verbalistis semata melainkan keteladanan dan tindakan-tindakan nyata.

Etika siswa di dalam mengikuti proses belajar mengajar melalui daring, menjadi hal yang sangat menentukan tentang hasil belajar itu sendiri. Oleh karena itu, siswa harus menyadari proses belajar mengajar daring sama nilainya dengan

paedagogia 3, no. 1 (2020): 97-104. 
proses belajar tatap muka misalnya, dalam proses pembelajaran daring siswa harus menunjukkan sikap menghormati guru dengan cara ikut aktif dalam proses belajar dan mengikuti prosedural yang ditentukan oleh guru seperti, selama pembelajaran berlangsung siswa harus on time, mengaktifkan video, berpakaian yang sopan, gesture tubuh yang menunjukkan keseriusan terhadap proses belajar dan berbicara pada waktu yang ditetapkan oleh guru dan tidak keluar dari kelas daring sebelum pembelajaran selesai.

\section{Implikasi}

Etika terhadap guru sangat berperan penting bagi siswa untuk keberhasilannya sendiri sebagai siswa, baik pada masa belajar maupun kelak di masa depan terutama di masa pandemi ini. Memperlakukan guru dengan etika yang baik merupakan cara yang baik dalam menempatkan diri sendiri untuk menerima etika yang baik pula dari orang lain termasuk guru. Karena itu, maka sangat penting bagi siswa untuk memiliki etika sebagaimana diuraikan di atas. Demikian halnya dengan guru, perlu memiliki komitmen untuk menjadi teladan dalam hal etika pembelajaran. Karena siswa selalu menjadikan guru sebagai mirror bersikap atau berperilaku dalam pembelajaran bahkan dalam kehidupan sehari-hari.

\section{Saran Tindak Lanjut}

Dengan memperhatikan uraian di atas, maka ada beberapa saran tindak lanjut untuk dilakukan oleh sekolah dalam rangka membangun etika siswa terhadap guru, yaitu sebagai berikut: pertama, menjadikan pendidikan karakter dan etika sebagai pendidikan dasar di Sekolah saat orientasi pengenalan sekolah. Dengan demikian, sejak awal siswa dididik untuk memiliki etika yang baik terhadap guru. Kedua, Sekolah meningkatkan peran Bimbingan Konseling secara holistik. Guru BK tidak hanya berperan ketika ada siswa yang melanggar aturan, tetapi pembina etika siswa secara berkala bekerja sama dengan guru-guru Mapel lainnya terutama guru agama. Ketiga, Sekolah mengembangkan Kebijakan Kurikulum Berbasis Akhlak. Mata Pelajaran agama harus mengorientasikan pelajaran etika secara berkelanjutan. Keempat, Sekolah menggelar pertemuan-pertemuan berkala sesering mungkin untuk mensosialisasi-kan etika siswa terhadap guru di luar pidato apel bendera pada hari Senin. Kelima, Sekolah mendorong orang tua siswa untuk lebih intens menasihati anak-anak di rumah perihal etika terhadap guru.

Kemudian Etika guru terhadap siswa juga perlu terjadi, di mana guru harus berpikir positif, penilaian yang baik kepada siswa, demi mendapat hubungan yang 
relevan, tugas guru dalam etika sosial terutama adalah memahami peserta didik dengan segala baik-buruk mereka agar menemukan relasi dan komunikasi yang baik, guru harus serba mampu dalam berbagai aspek etika siswa, mulai dari menegur sekaligus menasihati, berbicara tegas tanpa harus melontarkan kata-kata negatif, bersikap adil disertai dengan mewujudkan kasih.

\section{DAFTAR PUSTAKA}

Azzahra, Nadia Fairuza. "Mengkaji Hambatan Pembelajaran Jarak Jauh Di Indonesia Di Masa Pandemi Covid19." Ringkasan Kebijakan 19, no. 2 (2020).

Bagus, Lorens. Kamus Filsafat. Jakarta: PT Gramedia Pustaka Utama, 2000.

Bakry, Hasbullah. Sistematika Filsafat. Jakarta: Jakarta Wijaja, 1978.

Depdiknas. Kamus Besar Bahasa Indonesia Pusat Bahasa. Jakarta: PT Gramedia Pustaka Utama, 2008.

E. Mulyasa. Menjadi Guru Professional, Menciptakan Pembelajaran Kreatif Dan Menyenangkan. Bandung: Remaja Rosdakarya, 2005.

Elkind, David H; Sweet, Freddy. "How to Teach Character Education." Good Character. Accessed April 30, 2021. https://www.goodcharacter.com

Hermawansyah, Herwansyah. "Etika Guru Sebagai Pendidikan Yang Mendasar Bagi Siswa." Jurnal Studi Pendidikan 10, no. 2 (2019).

Huda, Nurul. "Pendekatan-Pendekatan Pengembangan Kurikulum" II, no. September (2019).
Lase, Delipiter, and Etty Destinawati Hulu. "Dimensi Spritualitas Dalam Kompetensi Kepribadian Guru Pendidikan Agama Kristen.” SUNDERMANN: Jurnal Ilmiah Teologi, Pendidikan, Sains, Humaniora dan Kebudayaan 13, no. 1 (2020).

Manuliang, Hendra Crisvin. "Pendidikan Agama Kristen (PAK)." 3 Maret 2017 (2017).

Purwanto, Ngalim. Ilmu Pendidikan Teoretis Dan Praktis. Bandung: Remaja Rosdakarya, 1994.

Putra, Hilmi Mubarok, Deka Setiawan, and Nur Fajrie. "Perilaku Kedisiplinan Siswa Dilihat Dari Etika Belajar Di Dalam Kelas." Prakarsa paedagogia 3, no. 1 (2020).

Qori, Imam. "Analisis Dampak Pembelajaran Daring Terhadap Guru Dan Peserta Didik Perspektif Teori Etika" (2019).

Rahmayani, Irma. "Pengaruh Gaya Belajar Terhadap Prestasi Belajar Mahasiwa." Fakultas Kedoteran, 2017.

Ryan, Kevin; Bohlin, Karen E. Building Character In Schools. San Fransisco: Jossey Bass, 1999.

Santika, I Wayan Eka. "Pendidikan Karakter Pada Pembelajaran Daring." Indonesian Values and Character Education Journal 3, no. 1 (2020).

Surya, Muhammad. Psikologi Pembelajaran Dan Pengajaran. Bandung: Yayasan Bakti Winaya, 2003.

Tantri, Yudi Heriana. "Kendala Dan Solusi Belajar Pada Masa Covid-19." Koran Bernas. Last modified 2020. Accessed April 25 , 2021. https://www.koranbernas.id

"Kamus Besar Bahasa Indonesia (KBBI)." Last modified 2012. Accessed March 10, 2021. https://kbbi.web.id/murid. 
54 | SANCTUM DOMINE: Jurnal Teologi, vol. 11, no. 1 (2021)

"Kemendikbud Terbitkan Pedoman Penyelenggaraan Belajar Dari Rumah." Kemendikbud. Last modified 2020. Accessed April 30, 2021. https://www.kemdikbud.go.id

"Medan Bisnis Daily." Medan Bisnis Daily. Last modified 2016. Accessed April 30, 2021.

https://www.medanbisnisdaily.com/. 